\title{
Development of Community-Based Tourism in Pinusan Kragilan, Pogalan Village, Magelang Regency, Central Java, Indonesia
}

\author{
Gatot Sasongko ${ }^{1}$, Bagus Trianggono*2, Pamerdi Giri Wiloso² \\ ${ }^{1}$ Faculty of Economic and Bussines, Satya Wacana Christian University, Salatiga, Indonesia \\ ${ }^{2}$ Faculty of Interdiscipline, Satya Wacana Christian University, Salatiga, Indonesia
}

\begin{abstract}
The purpose of this study is to describe community involvement in the development of Kragilan Top Selfie Pinusan tourist destinations (TSPK) and explain the role of Tourism Awareness Groups (Pokdarwis) in developing TSPK tourist destinations. This study uses the concept of Community-Based Tourism (CBT) as an analytical framework. The method used in this study is a qualitative research method. Data collection techniques were carried out by observation, documentation, and in-depth interviews with parties related to TSPK tourist destinations. The results of the study indicate that community participation in the process of developing the TSPK was encouraged by the local community namely Pokdarwis (tourism-aware group). Pokdarwis, in this case, plays a role in the division of labor; financial management; and managing cleanliness. Pokdarwis conducts division of labor to encourage community participation. The forms of community participation in TSPK include workforce and the contribution of ideas in developing TSPK. Next, the existence of TSPK also empowers the economy of the people in Kragilan Hamlet. Pokdarwis also empowers the community to manage the environment around the destination. Then TSPK shows that the CBT model that is different from CBT in general, in TSPK empowerment is carried out independently by Pokdarwis. Only after Pokdarwis initiated this empowerment and brought economic benefits, the government (Mount Merbabu National Park Office) took part in helping TSPK management.
\end{abstract}

Keywords: Community Based Tourism (CBT); Community Engagement; Participation; Top Selfie Pinusan Kragilan (TSPK)

\section{INTRODUCTION}

Tourism is interpreted as the new industry that can produce rapid economic growth in the provision of employment, increasing income, improving living standards and stimulating other sectors [1]. Therefore, tourism can be said to be a strategic sector for the development of a country. Therefore, the Indonesian government sets the tourism sector as one of the national development priorities. This sector has enormous potential to continue to be developed. It supported by 14.04 million foreign tourists visiting in 2017 - an increase of 21.88 percent compared to 2016 [2]. It means that with this percentage, there is still an opportunity to grow the Indonesian economy through tourism. This growth can occur if tourism planning carried out consistently and continuously. One way to make the tourism sector sustainable is the existence of community involvement, starting from the planning process [3]. Such involvement will encourage the emergence of communitybased tourism. This concept began to develop in Indonesia since 1980, and Yogyakarta was the first region to develop tourism in this model [4].

The concept of community-based tourism (CBT) is a new paradigm in tourism development. CBT is very different from mass tourism. CBT is not a tourism business that aims to maximize profits for investors. $\mathrm{CBT}$ is more related to the impact of

Correspondence address:

Bagus Trianggono

Email : bagust.0902@gmail.com

Address : ال I. Diponegoro 52 -60, Salatiga 50711 tourism on local communities and environmental resources [5]. Besides, according to Muallisin, CBT was born from a community development strategy by using tourism as a tool to strengthen the capabilities of rural/local organizations [6]. Some definitions of CBT have been put forward by several experts. Murphy considers that the community must be involved in tourism planning. Suansri emphasizes that CBT is a tool for community development and environmental conservation and that in community development, several things must be considered, including management and learning [7]. Pantin and Francis emphasize that tourism will positively correlate with improving the economy of a community [8]. Therefore, in general, CBT consists of 4 (four) main dimensions, namely community involvement, community development, community economic empowerment, and environmental conservation $[7,8,9]$.

There have been many studies conducted related to aspects of $\mathrm{CBT}$. Research on community participation and community involvement had been carried out by Su and Wall [10], Yulianie [11], Bambar and Anoma [12]. Su and Wall focused on the development of China Wall tourism where they found a positive correlation between community involvement and increased community income [9], while Yulianie focused on community participation and empowerment in managing Ceking's rice terrace attraction, Gianyar Bali while [10]. Bambar and Anoma focused on community participation in the development of Pandawa Beach tourism in Bali 
[12]. The three studies above present community involvement in certain tourism objects, but they have not yet described the involvement of the community as a group in developing tourism objects.

Research on community involvement as a group in tourism had been carried out by several researchers. Purnamasari found that there was a need to increase the capacity of the community to create tourism products that had a competitive and comparative advantage in the international market in Toddabojo Village [13]. Putra focused on the role of Pokdarwis in the development of the attraction of Tembi tourism village, Sewon subdistrict, Bantul Regency [14]. Noho focused on the management of the Gorontalo Bongo religious tourism village which in this study, he found that there was a need for increased capacity in religious tourism, attraction management and tourist services [15]. Community is described as an entity in togetherness in terms of formulating common interests, division of labor, and environmental conservation.

Research on economic empowerment in the field of tourism had been carried out previously. Arieta focused on the success of coastal tourism from the point of view of community empowerment as a concept of generating community strength in a bottom-up manner and improving the quality of life of the community [16]. Dewi focused on social and economic empowerment of rural communities in the management of Tanah Lot [17]. The results of the study show that the community can provide material benefits in the form of additional income that can help the economy of the family and the community. Rahayu et al focused on community economic empowerment strategies in Kulon Progo Regency, Yogyakarta [18]. However, the three studies only focus on economic empowerment and opening up the field for the community, but have not touched on environmental conservation.

Research on environmental conservation had been carried out by Dewi and Rosyidie, which focused on the development of the Capolaga Region as an Ecotourism Attraction [19]. Meanwhile, Saraswati et al focused on assessing sanitation facilities for tourists at Depok Beach [20].

Based on previous studies on aspects of CBT, there has been no research that focuses on the description of the concept of CBT in a tourism destination. Besides, no research focuses on tourist sites that are truly built, managed, and developed independently by the community. Therefore, there is still an opportunity to examine the involvement of the community as a group in the development of tourism objects in the perspective of CBT.

One of the destinations which the model of community involvement which developed as a group is Top Selfie Pinusan Kragilan (TSPK). TSPK is one example of a destination that adheres to the CBT system. At TSPK, the community has a role to empower local people and involve local people in the process of developing TSPK. The destination development model is carried out by the community with a bottom-up model. Initially, this destination opened in 2015 under the name Hutan Pinus Kragilan (Pinus Forest of Kragilan), but in 2016 this destination changed its name to TSPK. Within three years, this destination was in great demand by tourists. Based on data from the Tourism Awareness Group (Pokdarwis) in TSPK, there were 31,008 tourists coming from May to July 2018. Therefore, this is the reason for choosing TSPK as the location of research in this study. Based on the explanation of the background, the researchers will focus on the description of community involvement as a group in the development of tourism objects. The researchers use the concept of CBT as an analysis tool. The four dimensions in CBT will be for exploration of community-based tourism at TSPK.

\section{MATERIAL AND METHOD Study Area}

This research was conducted in the Top Selfie Pinusan Kragilan (TSPK) tourist destination. This destination located in Kragilan Hamlet, Pogalan Village, Pakis District, Magelang Regency. Kragilan Hamlet is part of Pogalan Village, Pakis District, Magelang Regency which located at an altitude of \pm 1330 masl. Kragilan Hamlet borders several villages, including Jambewangi Village in the east, Kajangkoso Village in the west, Gumelem Village in the south, and Kaponan Village in the north. The population in Kragilan Hamlet is 267 consisting of 136 male residents and 131 female residents.

Then most of the people of Krgailan Hamlet work as vegetable farmers. The commodities planted by the people of Kragilan Hamlet are vegetables such as cabbage, chili, and other vegetables. Then since 2015 the Kragilan Hamlet, Pogalan Village, Pakis Subdistrict, Magelang Regency has become famous for the emergence of Kragilan Top Selfie Pinusan tourist destinations. This destination is one example of a tourist destination that developed and managed independently by the community. Visually the Kragilan Hamlet map is shown in Figure 1; then the TSPK destination and vehicle at TSPK are shown in Figure 2. 


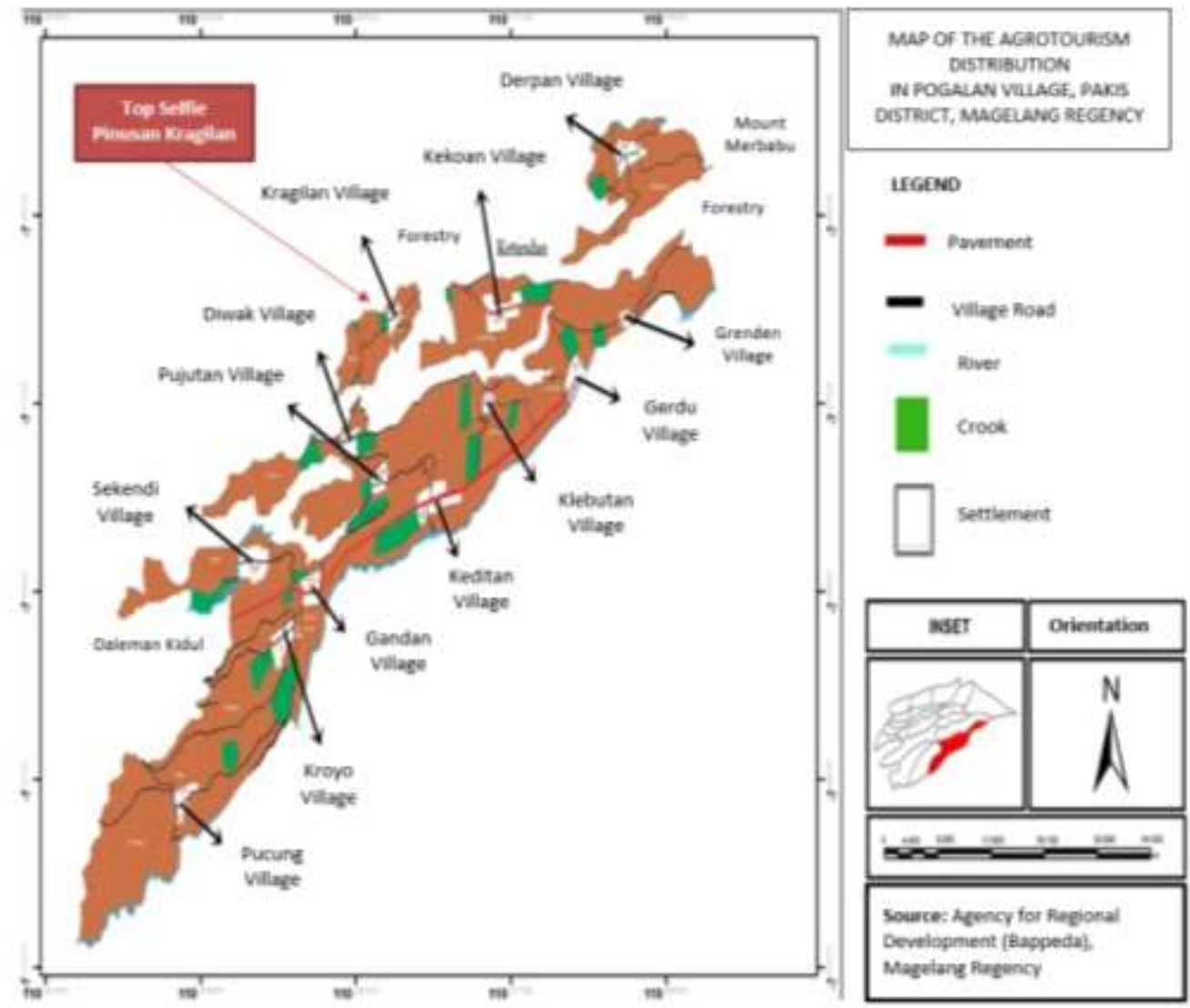

Figure 1. Map of Pakis District, Magelang Regency

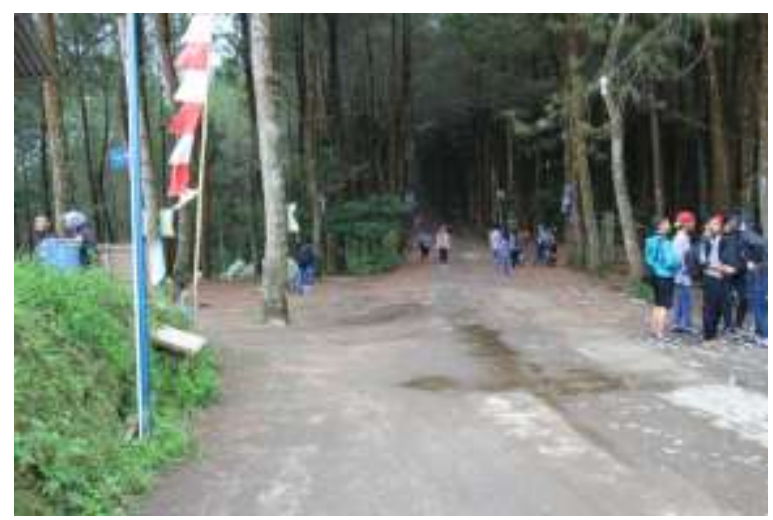

Figure 2. TSPK Destination Location (Source: Personal Documentation, 2018)

\section{Data Collection and Analysis}

This study uses an ethnographic approach.In the process of collecting data, researchers conducted observation, documentation, and indepth interviews. This research was conducted from November 2017 and ended in June 2018. In November 2017, researchers conducted preliminary observations and adaptations to the research environment.

In the process, the researcher begins to map out the actors involved in the TSPK destination. Then the researchers also observed various activities of workers, tourists, and traders around TSPK. The observations were carried out by researchers until the end of December 2017. January 2018 researchers began looking for informants who would be asked for information related to TSPK, starting from the history of the formation of the TSPK until its development to date.

Based on observations made since November 2017, the researchers finally found several key informants namely the Pokdarwis head of TSPK, the Pokdarwis field coordinator, parking attendants, photographer officers, shop owners, and tourists. The process of in-depth interviews with informants was carried out by researchers for one month, January 2018 to February 2018, there were various obstacles experienced by researchers such as obstacles when the informant suddenly canceled the interview at the appointed time.

However, finally the process can be overlooked and finally the researchers get all the information needed related to TSPK. The data analysis was carried out in several stages, including finding and compiling systematic data through interview transcripts, field notes, and accumulated documentation that add the researchers' understanding of what were found [21]. 


\section{RESULT AND DISCUSSION}

\section{Process of TSPK Establishment}

The village of Kragilan is a region that may not be widely known to people before the forming of TSPK. It is not an easy endeavor to create TSPK since various processes must be passed through until finally formed. Starting from 2015, residents of Kragilan village are working together to improve the infrastructure of the village entrance. In the development process, several young men took pictures in the construction area against a backdrop of pine forests. The result of the selfie then uploaded to social media (Facebook). After uploading, the netizens who saw the photo gave a response by asking where the photo was taken. Starting from this event, many people came to the Kragilan pine forest. The arrival of tourists then led to the initiative of the youth of the village to develop the Kragilan pine forest into a new tourist destination.

The first step they did was to ask permission from the Head of village, to manage and build a tourist destination for Kragilan pine forest, and he finally allowed this idea. The young people ask the Karang Taruna (village's youth organization) to form security and parking teams with the permission of the head of the village to maintain security around the destination. Throughout MayDecember 2015, about 30-50 tourists came every day (personal communication, 2018). On this basis, the Karang Taruna took the initiative to form a special community to manage the Kragilan pine forest destination. Through various processes at the beginning of 2016, the Top Selfie Pinusan Kragilan Tourism Awareness Group (Pokdarwis TSPK) was finally formed which consists of young people and the Kragilan village community, and they inaugurated the name of this tourist destination as Top Selfi Pinusan Kragilan (TSPK). The name of Top selfie was given because it has become a trend in the current era. The leader of Pokdarwis in 2016 was SB, and he is still in office up to now. After Pokdarwis was formed, problems arose related to land ownership.

Juridically, the land is owned and managed by the Mount Merbabu National Park Office.
Therefore Pokdarwis is normatively violating the rules regarding land use because it did not ask permission from the National Park Office. Then in 2017, Pokdarwis submitted a proposal to manage a portion of the Kragilan pine forest. In February 2018, the Mount Merbabu National Park Office gave management recommendations to Pokdarwis covering 4 hectares. The consequence of this is that Pokdarwis cannot manage the TSPK by themselves because they must involve the Mount Merbabu National Park Office and this agreement was finally agreed by both parties. With this joint management, on February 14, 2014, the Top Selfie Pinusan Kragilan tourism destination (TSPK) was officially opened, but the name of Pokdarwis changed into KSWT (Top Selfi Tourism Awareness Group).

It shows that there is a unique feature in the emergence of Pokdarwis at TSPK. Where pokdarwis emerged at the initiative of the local community, then, in the end, the community formation committee could collaborate with government (Mount Merbabu National Park Hall) to collaborate in managing the TSPK. Therefore, the findings at TSPK are an interesting finding where this is an antithesis of the CBT concept that only puts forward the bottom-up model, but the findings at TSPK show the collaboration of bottomup and top-down models.

The bottom-up model is the formation of Pokdarwis by the local community, and the topdown model is the state (Mount Merbabu National Park) intervention on the land at TSPK. Thus, the findings at TSPK became interesting (Figure 4). It was different from the findings of Wirajuna and Supriyadi who found that the Pokdarwis formed in Jerowaru West Nusa Tenggara was initiated by the village government [22]. The difference shows that Pokdarwis TSPK was formed at the initiative of a new community that later penetrated the government. A different finding was in line that Pokdarwis in Bendosari village formed by the village government to improve the community's economy [23], while in TSPK Pokdarwis was formed to accommodate community interest in developing TSPK.

\begin{tabular}{|c|c|c|c|}
\hline 2015 & 2016 & 2017 & 2018 \\
\hline $\begin{array}{l}\text { Karang Taruna } \\
\text { requested } \\
\text { permission from } \\
\text { the Village Head } \\
\text { and formed a } \\
\text { parking division for } \\
\text { tourists }\end{array}$ & $\begin{array}{l}\text { Forming the Top } \\
\text { Selfie Pinusan } \\
\text { Kragilan Tourism } \\
\text { Awareness Group } \\
\text { (Pokdarwis TSPK) }\end{array}$ & $\begin{array}{l}\text { Pokdarwis } \\
\text { applied for a } \\
\text { management } \\
\text { permit for the } \\
\text { Kragilan Pine } \\
\text { Forest }\end{array}$ & $\begin{array}{l}\text { Pokdarwis TSPK } \\
\text { changed into Top } \\
\text { Selfi Tourism } \\
\text { Awareness Group } \\
\text { (KSWT) collaborated } \\
\text { with Mt. Merbabu } \\
\text { National Park }\end{array}$ \\
\hline
\end{tabular}

Figure 4. Process of TPSK establishment 


\section{Community Participation in Building of TSPK}

The community of Kragilan village is the main actor in the TSPK development process. The community plays an active role in the process of developing TSPK. This active role was supported by the existence of the Tourism Awareness Group (Pokdarwis). Pokdarwis has a role in building the tourism system in TSPK by involving the community, including the involvement of the community as laborers at TSPK, providing ideas for TSPK development. The process was carried out during meetings between divisions every month. During the meeting, Pokdarwis members and community members who were present free to express their opinions.

"Sir, for the progress of top selfie, all may give their ideas. Anyway, all ideas can be submitted every $12^{\text {th }}$ date as long as they are important for the sake of top selfie, they are will be accepted. Sir, the inspiration to make a tourist park as a comparative study such as the fruit garden in Jogja can be an example of it. Other examples are Kalibiru and Pecici. From the Internet, there are also many examples like Maribaya, which is nearly the same as here" $-S$

The statement shows that Pokdarwis has fulfilled the criteria of Dahl about democracy, which is about freedom of organization and expression [24]. Freedom of organization and expression reflected in active participation in contributing ideas for the development of the tourist area and the community was also involved by Pokdarwis to determine the price of photographer services. The ideas of the community were discussed at regular Pokdarwis meetings every month. The tariff for each tourist area varies from IDR 5,000 to IDR 20,000.

These findings indicate that there is the existence of one CBT concepts, namely the involvement of local communities in tourism development planning. Such involvement was supported by Pokdarwis. The community involvement was also influenced by social capital. Putnam stated that social capital is in the form of social organizations, beliefs, norms, and networks (from community ties) [25].

In the context of TSPK, the involvement of the local community in TSPK development planning seen in social bonds in the form of trust and networks. Trust was built because of the common vision between members and administrators of Pokdarwis. The network will form a common bond for the progress of the TSPK. In the tourism planning process, the parties involved were the management and members of the Pokdarwis TSPK.
Based on the exposure of the research findings above, it shows that TSPK destination was formed and developed because of the community involvement. Community involvement in TSPK was provided by Pokdarwis. Pokdarwis itself was formed due to community initiatives to develop TSPK. It is similar to the findings by Bambar and Anoma, who found that community participation shown by the active participation of the community in making decisions to improve the quality of Pandawa beach tourism [12].

However, it was not specifically mentioned that the form of community activity was accommodated by the government. It is different from the findings at TSPK, which shows that community activity was encouraged by the local community - Pokdarwis. Related to this issue, Yulianie found that the people of Tegallalang and Kedisan villages could not be maximally empowered because of the lack of tourism support facilities in which people could not feel the impact of the tourist attraction offered [11]. Therefore, table 1 will briefly explain the role of Pokdarwis development process TSPK.

Table 1. The Actors and Its Participation in TSPK

\begin{tabular}{|c|c|c|}
\hline Phase & Actor & Role \\
\hline \multirow[b]{3}{*}{$\begin{array}{c}\text { TSPK } \\
\text { pioneering }\end{array}$} & $\begin{array}{c}\text { Karang Taruna and } \\
\text { Pokdarwis TSPK }\end{array}$ & $\begin{array}{l}\text { Hold meetings with } \\
\text { the community }\end{array}$ \\
\hline & Kragilan Village & Provide input to the \\
\hline & Community & $\begin{array}{l}\text { TSPK development } \\
\text { process and assist in } \\
\text { the development of } \\
\text { the TSPK by working } \\
\text { together }\end{array}$ \\
\hline \multirow{6}{*}{$\begin{array}{c}\text { TSPK } \\
\text { Developing }\end{array}$} & $\begin{array}{l}\text { Kragilan Village } \\
\text { Community }\end{array}$ & $\begin{array}{l}\text { Building new land on } \\
\text { TSPK }\end{array}$ \\
\hline & $\begin{array}{l}\text { Leader Pokdarwis } \\
\text { TSPK }\end{array}$ & $\begin{array}{l}\text { Provide various inputs } \\
\text { for the development } \\
\text { of vehicles at TSPK }\end{array}$ \\
\hline & Photographer & $\begin{array}{l}\text { Agree on photo } \\
\text { service rates at TSPK }\end{array}$ \\
\hline & $\begin{array}{l}\text { Pokdarwis Parking } \\
\text { Division and } \\
\text { Kragilan Village } \\
\text { Community }\end{array}$ & $\begin{array}{l}\text { Agree on parking } \\
\text { rates at TSPK }\end{array}$ \\
\hline & $\begin{array}{l}\text { Pokdarwis and } \\
\text { Kragilan Village } \\
\text { Community }\end{array}$ & Agree on vehicle rates \\
\hline & Pokdarwis TSPK & $\begin{array}{l}\text { Share the workload of } \\
\text { the workforce at TSPK }\end{array}$ \\
\hline
\end{tabular}

The findings at TSPK show almost the same thing related to facilities, but the lack of Pokdarwis facilities continues to encourage the development of better TSPK. It also supported by active community participation in advancing TSPK. It is because the existence of TSPK improves the economic life of the community of Kragilan village. Regarding the economy of the community, TSPK 
shows the same phenomenon as the findings of $\mathrm{Su}$ and Wall in China, which showed that community involvement positively correlated with increasing community income [10]. The fact in Kragilan shows that although there had been no involvement of the government or the private sector (investors), TSPK was still able to develop and improve the economy of the community through the existence of community collectivity.

\section{Pokdarwis Role in TSPK Development}

Community development is one of the elements in CBT. In the context of the community of TSPK, it refers to the Group of Top Selfie Tourism Awareness (Pokdarwis TSPK). Pokdarwis is the main agency that drove the TSPK and formed in 2016. The establishment of Pokdarwis aimed as a place for the community of Kragilan village to develop the TSPK. The Pokdarwis plays a role in the job division for workers in TSPK; it played the role of the financial manager at TSPK and it was responsible for the cleaning of TSPK. Pokdarwis hierarchy consists of a chairman, secretary, treasurer, and there are 3 divisions who play their role in the field, namely parking and security division, photographer division, and the cleaning division. The job division of workers at TSPK was carried out by each relevant division, for example, in creating job shifts for photographers and parking. The creating of such job shift was fully carried out by the division of the photographer, and the parking and security division.

"Sir, the division of labor has been arranged in the organization, so as I said before, in each division, there is someone in charge. In the past, the job shift was set daily, so if someone got Monday shift, then he would get Monday again. But now, Sir, we use the Javanese calendar, so the shift of work day can change according to the calendar. Sir, the parking is arranged by the parking division, and because I'm the chairman, I know that each division also has its chairman. Sir, the chairman is the one who manages the shift." -S

The carried out shift model was twice shift period i.e. morning shift starting at $7 \mathrm{am}$ to $12 \mathrm{pm}$ and the afternoon shift starting at $1 \mathrm{pm}$ to $6 \mathrm{pm}$. In one shift, there were 7 (seven) photographers. Why was the shift model chosen, and why does it consist of 7 people? It is because there had been an agreement in Pokdarwis. With such divisions, it is expected that the entire community of Kragilan village may earn the economic benefits from the existence of TSPK. In addition, the shift division for parking was the same model with the model for parking and security officers.
Regarding financial management, includes the sources of income came from parking fees, retribution for photos, and retribution for rides in the tourist areas. With the average number of visitors reaching 500-1,000 people, it raises questions about the usage of the money. Retributions were used to develop TSPK such as for the construction of new areas and buying cameras for photographer services. In addition to developing TSPK, the results of retribution used for the organization, namely for social funds. Those who managed the money were the treasurer of Pokdarwis TSPK. Meanwhile, the cleaning division was responsible for the cleanliness of the area. Regarding the above findings, in the context of community development, Pokdarwis TSPK managed to regulate a good tourism system. Pokdarwis organized TSPK from the planning to development stages (Table 2).

Table 2. The Role of Pokdarwis TSPK

\begin{tabular}{ll}
\hline \multicolumn{1}{c}{ Division } & \multicolumn{1}{c}{ Role } \\
\hline Parking Division & $\begin{array}{l}\text { Divide the tasks of the parking } \\
\text { members and divide the parking } \\
\text { member shift }\end{array}$ \\
\hline $\begin{array}{l}\text { Photographers } \\
\text { Division }\end{array}$ & Divide the photographer's shift at TSPK \\
\hline Hygiene Division & $\begin{array}{l}\text { Ensure TSPK cleanliness and cleanliness } \\
\text { of supporting suggestions at TSPK such } \\
\text { as toilets }\end{array}$ \\
\hline $\begin{array}{l}\text { Treasurer of } \\
\text { Pokdarwis }\end{array}$ & $\begin{array}{l}\text { Manage finances from parking fees, } \\
\text { photographer services and rides and } \\
\text { pay workers (photographers, parking } \\
\text { members, and janitors) at TSPK) }\end{array}$ \\
\hline
\end{tabular}

The findings in the TSPK are different from the findings of Putra who found that Pokdarwis only played a role in the development of tourism attractions in the Tembi Tourism Village of Sewon District, Bantul Regency [14]. The findings at TSPK indicate that Pokdarwis organized the overall elements of tourism at TSPK. TSPK can exist from the community initiatives so that the entire planning process until the development process was carried out entirely by the community.

It is also different from the findings of Purnamasari which shows that the community is involved in tourism development because they get support from the government [13]. It means that the people of Kragilan village were independent and unwittingly they were empowered.

This independence was encouraged by the local community, namely Pokdarwis. The TSPK tourism development model through Pokdarwis was carried out with a bottom-up model, and the government with private sector had no role in developing TSPK. CBT that existed in TSPK was different from the CBT concept in general, which states that community involvement occurs if there 
is already a destination made by the private sector or government in the form of partnerships.

\section{Capacity Improvement for Workers at TSPK}

Pokdarwis TSPK besides performed its management function in organizing a community also performed a learning function. The purpose of the learning is to improve the quality of Human Resources (HR) for workers at TSPK. The forms of learning carried out by Pokdarwis were still limited. The learning was carried out every $9^{\text {th }}$ date at a meeting among photographers. The purpose of the meeting was to discuss any issues related to photography. The fact is that SB as the chairperson of Pokdarwis TSPK was the actor who played a role in improving the quality of human resources at TSPK. SB shared his knowledge with photographers about how to take pictures according to the applicable standards. The carried out learning process was photography class sessions. A photography class was held to discuss with each other about photography. The learning model in this class was done by brainstorming and photo practices. The person who gave lesson materials in the photography class session was the Chairperson of Pokdarwis TSPK.

This class session was very useful for photographers of TSPK destination. The perceived benefit is that photographers would understand more about how to take good pictures. It means that Pokdarwis had succeeded in the building of capacity for photographers in TSPK tourist destination. The main purpose of capacity building in learning comes from the needs of something and facing changes [26]. The context of learning that comes from the needs of something is the need to improve the skills and results of photographs while dealing with changes that happen when there are protests from visitors about the photo quality of photographers. Both of them had become the capacity building carried out by Pokdarwis TSPK.

Based on these explanations, by improving the quality of human resources through monthly meetings of photographers, Pokdarwis had performed the learning function. In addition, Pokdarwis had the ability to develop TSPK.

To increase the capacity of Pokdarwis, it needs to increase the capacity of individuals involved in Pokdarwis. However, different things found by Damayanti et al which shows that there was a complexity in increasing the capacity of the community of Bendosari Village of Pujon Subdistrict, Malang Regency [27]. That is improving the quality of human resources, strengthening the organization, and institutional reform. The effect of this complexity was the ineffectiveness of the strategy taken [28]. It showed the weaknesses of the strategy carried out by the government of Bendosari Village, and there was no involvement from the Malang Regency government [27].

Different findings took place at TSPK. Although the carried out capacity building was still limited, but it was more effective in improving the quality of human resources, especially photographers at TSPK. Even so, the capacity of the community increased, especially in the field of photography, because the photographers held meetings every month to overcome the community who did not know how to use a camera properly. After discussion at the meetings, the knowledge of the community increased, and the creativity of photographers at TSPK also increased as well.

\section{New Economic Potential for the Community of KragilanVillage}

The existence of TSPK had a positive correlation with the development of tourism supporting businesses, including parking, photography services, and food stalls. The existence of these businesses opened up new jobs for the Kragilan people who previously worked as vegetable farmers.

Based on the observations of researchers, income for Pokdarwis from the parking sector was very large. Retribution for car parking at TSPK was IDR 10,000 and IDR 3,000 during the initial opening of TSPK. Determining parking fees was very dynamic at TSPK. However, at the beginning of 2017, the retribution had been changed where there was an additional cleaning fee for IDR 2,000.

The change occurred again when the Mount Merbabu National Park Agency became part of the TSPK manager. Retribution for one person was IDR 10,000 consisting of IDR 5,000 for TSPK and IDR 5,000 for the national park agency. However, noted that through various dynamics of changes in retribution costs, the positive thing from it was the opening of jobs for the people of Kragilan village. People who were in charge of parking management at TSPK got paid IDR 25,000 per assignment. The assignment was valid once a week.

Besides the involvement of the community in managing TSPK parking, they also involved in the services of photographers at TSPK. The rate for photographers for one photo was IDR 2,500. In addition to photo division, there was also photo services for visitors who wanted to use the tourist area as the background of their photo. However, the prices for background photos were set separately, i.e. IDR 2,500 only for photo services, while for the background (in this case the tourist 
area) was case dependent (the benchmark price was between IDR 5,000 to IDR 20,000).

For the community involved as parking staff members and photographers, they earned IDR 25,000 every day. On average, each month the participated people might get IDR 400,000 per month. It would not be the case if they were dependent on the agricultural sector, in which prices based on market prices. It shows that tourism that was built by the community at TSPK can improve their economy. However, these staff was obliged to deposit money into the community cash with an amount of IDR 50,000 every time they were on duty. The deposit was imposed on seven people on duty, meaning that each staff got deduction from their salary of IDR 7,000 per one assignment. This deduction used for the cash of Pokdarwis. The involvement of the community in the development of the TSPK had resulted in TSPK to develop rapidly, and the community can be more prosperous with the presence of TSPK. It is in line with Damanik's statement that community involvement is the key to improve welfare through tourism development [29].

The next business that also developed at TSPK was food stalls. The existence of these stalls was a direct effect of festive TSPK. Based on the observation of researchers, there are four food stalls actively trading. The owners of the stalls were local residents. The things that sold at the stalls include:

"Sir, here we offer coffee, tea, and pop noodles. There are also snacks. See that those are the newest things we can offer. Besides, coffees and teas are suitable for the atmosphere here. Sir, this site is quite cold, so drinking a hot drink would make the atmosphere warm. Those who run the stall businesses here are the local people, who used to have no work at all and now they have activities to manage food stalls here, " $-F$

The existence of these food stalls had improved the economy of the local community and reduced the unemployment rate at the village of Kragilan. The food stall business in TSPK will continue to grow in line with the growing of TSPK. TSPK is currently one of the favorite tourist destinations in the Magelang Regency. The food stalls were managed independently by stall owners. However, the arrangement of trade location was regulated by Pokdarwis, i.e. by parking and security divisions. The divisions regulate the trading location to prevent crowded stalls at TSPK.

Based on these findings, it seems that the existence of TSPK had a positive effect on the community, namely the growth of employment for the people of Kragilan village. The findings by
Arieta proved that the community collectivity increased their quality of life [16]. The findings in Kragilan also show that the community's quality of life, especially in the economic sector improved because of the existence of TSPK. It was through the development of businesses and involvement of the community as workers in TSPK.

Dewi found that people earned additional income from the tourism of Tanah Lot in Bali. The findings in Kragilan show differently, where some people especially youth, relied on jobs at TSPK as their main source of income [17]. Some say that TSPK as the side income in addition to income as vegetable farmers. It means that TSPK had reduced unemployment in the Kragilan village, in which there were 53 out of 267 community members who involved as workers in TSPK.

The findings of Rahayu et al show that the obstacles leading to economic empowerment that runs non-optimally, i.e. unsupported infrastructure, community participation is still low in developing of tourism, and partnership that has not maximally built [18]. These three factors also experienced by actors in the TSPK, but the difference was related to participation. The community in Kragilan was very enthusiastic to develop TSPK. With this high community enthusiasm, the economy of the community will increase. The economy improved because of the absorption of the community as workers in TSPK.

\section{Community Awareness in Managing the Environment}

CBT cannot be separated from environmental conservation. Environmental conservation in the context of TSPK is a type of conservation viewed by TSPK. Pokdarwis, through the hygiene division, was responsible for managing waste around the destination and cleaning up the supporting facilities, such as toilets. To carry out this task, the hygiene division cannot work alone, and it needed participation from tourists. It means that the cleanliness of the TSPK environment was a shared responsibility between Pokdarwis and tourists.

In general, supporting facilities at TSPK that produced waste include toilet and food stalls, so the two supporting facilities must always be monitored. If facilities at TSPK are dirty, tourists will think twice to come to TSPK. The toilet at TSPK is a very important supporting facility. For tourists who came from outside the city, they usually look for toilets first to urinate or just to wash their faces. Therefore, with this crucial function, toilets must be kept clean. With a clean and comfortable toilet, it will give a positive impression to tourists. Related to this issue, the division that had a role in toilet hygiene at TSPK was the Pokdarwis hygiene 
division. The cleaning division had the task of checking up tap water and ensuring that all toilets are always clean and comfortable for tourists.

This process indicates that people in Kragilan village who are members of Pokdarwis realized that aspect of comfort is important in the tourism business. It means that with the awareness of maintaining cleanliness, the community was at the stage of apathy. The apathy stage is the stage where people accept tourists as a normal thing and the relationship between people and tourists dominated by commercial relations. The planning that was carried out in a tourist destination in this phase generally only emphasizes the marketing aspect [29].

Related to environmental conservation, Dewi and Rosyidie found that there needs to be awareness from the community about the environmental quality and education in developing ecotourism [19]. Therefore, to improve the quality of sanitation and hygiene at TSPK, the role of the government is needed to encourage people to continue maintaining cleanliness at TSPK so that tourists will feel comfortable visiting TSPK.

Next, the findings of Saraswati et al that the condition of sanitation facilities in Depok Beach Bantul was stated to be healthy [19]. Sanitation hygiene is important in a tourism system, which findings at TSPK indicate that toilet hygiene in TSPK needs to be improved. Therefore, in the future it is expected that there will be improvements in the toilet as a supporting tool at TSPK. With these improvements, it is expected that the satisfaction of tourists visiting TSPK will be increased.

\section{CONCLUSION}

Pokdarwis becomes an institution that plays an important role in the planning process of TSPK development. Pokdarwis organizes various aspects to make TSPK continue to develop, such as establishing a system of division of labor, managing finances resulting from retribution, and improving the quality of human resources in Kragilan village. In the planning and development process, TSPK Pokdarwis always involves the community, and this involvement is shown by accommodating the opinions of Pokdarwis members and community members in monthly meetings. The existence of TSPK empowers the economy of local communities in the form of employment through parking and photographer services, and the emergence of food stall businesses around the destination. The cleaning division of Pokdarwis TSPK plays a role in environmental conservation at TSPK. The CBT model in Kragilan differs from CBT, theoretically, CBT in TSPK done with a pure bottom-up model.

\section{Acknowledgement}

The author thanks to those who have helped the writing of this article. Those parties include informants who were willing to provide information and Dr.Ir. Suwartiningsih, M.Sc for input on the concept of community empowerment.

\section{REFERENCES}

[1] Pendit, N. S. 1980. Ilmu pariwisata sebuah pengantar perdana. Pradya Paramita Publisher. Jakarta.

[2] Ministry of Tourism. 2016. Data jumlah wisatawan asing ke Indonesia. Ministry of Tourism, Republic of Indonesia. Jakarta.

[3] Ross, G. F. 1998. Psikologi pariwisata. Yayasan Obor Indonesia Publisher. Jakarta.

[4] Baiquni, M. 2017. Pariwisata berbasis masyarakat yang berkelanjutan: pariwisata oleh, dari dan untuk masyarakat. Available at: http://www.kombinasi.net/pariwisataberbasis-masyarakat-yang-berkelanjutanpariwisata-oleh-dari-dan-untuk-masyarakat/.

[5] Hadiwijoyo, S. S. 2012. Perencanaan pariwisata perdesaan berbasis masyarakat (sebuah pendekatan konsep). Graha IImu Publisher. Yogyakarta.

[6] Mualissin, I. 2007. Model pengembangan pariwisata berbasis masyarakat di Kota Yogyakarta. Jurnal Penelitian BAPPEDA Kota Yogyakarta 2, 5-15.

[7] Murphy, P. E. 1985. Tourism: a community approach. Routledge Library Editions. New York.

[8] Suansri, P. Handbook of community based tourism. Rest Project. Thailand.

[9] Pantin, D. and J. Francis. 2005. Community based sustainable tourism. UWISEDU. UK.

[10] Su, M. and G. Wall. 2014. Community participation in tourism at a world heritage site: Mutianyu Great Wall, Beijing, China. Journal Tourism Research 16, 146-156.

[11] Yulianie, F. 2015. Partisipasi dan pemberdayaan masyarakat dalam pengelolaan daya tarik wisata "Rice Terrace" Ceking, Gianyar. JUMPA 2(1), 165-184.

[12] Bambar, A. F. and I P. Anoma. 2016. Partisipasi masyarakat dalam pengembangan pariwisata di Pantai Pandawa, Desa Kutuh, Kuta Selatan, Badung. Jurnal Destinasi Pariwisata 4(2), 36-43.

[13] Purnamasari, A. M. 2011. Pengembangan masyarakat untuk pariwisata di Kampung Wisata Toddabojo Provinsi Sulawesi Selatan. Ministry of Marine and Fisheries, Republic of Indonesia. Jurnal Perencanaan Wilayah dan Kota 22(1), 49-64. 
[14] Putra, T. R. 2013. Peran pokdarwis dalam pengembangan atraksi wisata. Jurnal Pembangunan Wilayah dan Kota 9(3), 225235.

[15] Noho, Y. 2014. Kapasitas pengelolaan desa wisata Religius Bongo Kabupaten Gorontalo. Jurnal Nasional Pariwisata 6(1), 8-21.

[16] Arieta, S. 2010. Community Based Tourism pada masyarakat pesisir; dampaknya terhadap lingkungan dan pemberdayaan ekonomi. Jurnal Dinamika Maritim 2(1), 7179.

[17] Dewi, L. G. L. K. 2013. Usaha pemberdayaan sosial ekonomi masyarakat Desa Beraban dalam pengelolaan Tanah Lot secara berkelanjutan. Jurnal Analisis Pariwisata 13(1), 32-44.

[18] Rahayu, S., U. Dewi, and K. N. Fitriana. 2016. Pengembangan Community Based Tourism sebagai strategi pemberdayaan ekonomi masyarakat di Kabupaten Kulon Progo, Daerah Istimewa Yogyakarta. Jurnal Penelitian Humaniora 21(3), 1-13.

[19] Dewi, Y. K. and A. Rosyidie. 2008. Kajian pengembangan kawasan Capolaga sebagai daya tarik ekowisata. Jurnal Perencanaan Wilayah dan Kota 19(2), 23-36.

[20] Saraswati, L. Aslinda, I. Werdiningsih, and Purwanto. 2016. Evaluasi kondisi sarana sanitasi yang disediakan Dinas Kebudayaan dan Pariwisata dan tingkat kepuasan wisatawan Pantai Depok, Bantul, Yogyakarta, Tahun 2016. Sanitasi, Jurnal Kesehatan Lingkungan 8(2), 64-72.

[21] Usman, H. and P. S. Akbar. 2009. Metodologi penelitian sosial. Bumi Aksara Publisher. Jakarta.

[22] Wirajuna, B. and B. Supriyadi. 2017. Peranan kelompok sadar wisata untuk meningkatkan keamanan wisatawan (Studi Kasus di Jerowaru Nusa Tenggara Barat). Jurnal Pariwisata Pesona 2(2), 1-15.

[23] Wijaya, S. A., Zulkarnain, Sopingi. 2016. Proses belajar kelompok sadar wisata (pokdarwis) dalam pengembangan Kampoeng Ekowisata. Jurnal Pendidikan Nonformal 11(2), 88-96.

[24] Dahl, R. 1998. On democracy. Yale University Press. New Haven and London.

[25] Putnam, R. 1993. Making democracy work: civic. Tradition in modern Italy. Princeton University Press. Princeton.

[26] Khawaja, S. and K. T. Morison. 2001. Measuring statistical capacity building: a logic framework approach. International Monetary Fund Available at: https://www.imf.org/ external/pubs/ft/wp/2001/wp01188.pdf.
[27] Damayanti, E., M. S. Soeaidy, H. Ribawanto. 2015. Strategi capacity building pemerintah desa dalam pengembangan potensi Kampoeng Ekowisata Berbasis Masyarakat Lokal (studi di Kampoeng Ekowisata, Desa Bendosari, Kecamatan Pujon, Kabupaten Malang). Jurnal Administrasi Publik 2(3), 464470.

[28] Suharto, E. 2007. Modal sosial dan kebijakan publik. Available at: http://www.policy.hu /suharto/Naskah\%20PDF/MODAL_SOSIAL_D AN_KEBIJAKAN_SOSIA.pdf

[29] Damanik, J. 2013. Pariwista Indonesia. Pustaka Pelajar Publisher. Yogyakarta. 